\title{
Flora of the cangas of the Serra dos Carajás, Pará, Brasil: Lamiaceae
}

\author{
Raymond M. Harley ${ }^{1,2,3}$
}

\begin{abstract}
This is an account of the species of Lamiaceae, which have been reported on canga substrates in the Serra dos Carajás, in the state of Pará, Brazil. Eight genera and 16 species are recorded. This includes both native and established adventive species. Keys, descriptions, illustrations and comments on the species are also provided. Key words: Ajugoideae, FLONA Carajás, fruit-type, Nepetoideae, Viticoideae.

\section{Resumo}

É apresentado o levantamento das espécies de Lamiaceae que ocorrem sobre o substrato de canga na Serra dos Carajás, no estado do Pará, Brasil. Oito gêneros e 16 espécies foram registradas, e são incluídas tanto as espécies nativas como as adventícias já estabelecidas. São incluídas chaves, descrições, ilustrações e comentários das espécies.
\end{abstract}

Palavras-chave: Ajugoideae, FLONA Carajás, forma de fruto, Nepetoideae, Viticoideae.

\section{Lamiaceae}

Lamiaceae Martinov is a large, nearly cosmopolitan family with about 250 genera, with its centre of diversity mainly in tropical and subtropical savannas, especially in montane areas, but is absent only from the coldest regions of high latitude or altitude. The family is divided into seven subfamilies, with almost 7200 species (Harley et al. 2004). The South American species were first studied in detail by Epling (1935, 1936a, 1936b, 1937). In Brazil, there are 38 genera and about 495 native species, with several genera and species introduced and naturalized (BFG 2015). Relatively few species occur in the Brazilian Amazon, and their collection in Amazonia has been relatively neglected (Harley 2012). 16 species have been recorded from the canga soils of the Serra dos Carajás, including one species introduced as a weed, from the Old World. The majority of Brazilian species belong to the Tribe Ocimeae subtribe Hyptidinae (see Bentham 1833, 1848; Briquet 1897; Epling 1949). The subtribe has recently undergone a major revision, based on molecular and morphological data (Pastore et al. 2011; Harley \& Pastore 2012). Many species have been removed from the genus Hyptis Jacq., involving numerous name changes. To facilitate the association of these new names, with those now obsolete but more familiar ones under Hyptis, synonyms have sometimes been added under the accepted names.

\footnotetext{
${ }^{1}$ Honorary Research Fellow, Royal Botanic Gardens, Kew, Richmond, Surrey, KT2 5PR, England, UK

${ }^{2}$ Museu Paraense Emílio Goeldi, Av. Magalhães Barata 376, São Braz, 66040-170, Belém, PA, Brazil.

${ }^{3}$ Author for correspondence: rharley05@hotmail.com
} 


\section{Key to genera of Lamiaceae in the canga of the Serra dos Carajás}

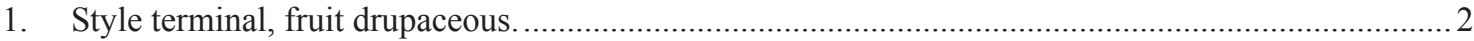

1'. Style gynobasic, ovary 4-lobed, forming a fruit of 4 dry mericarps (nutlets)..................................... 4

2. Leaves usually compound, opposite. Corolla 2-lipped. Fruit with 1 four-seeded pyrene.

2'. Leaves simple. Corolla \pm actinomorphic. Fruit with 1-4 one-seeded pyrenes.

3. Often dioecious shrubs or climbers with opposite leaves. Flowers, in axillary cymes often forming dense capitate or paniculate clusters or in a terminal thyrse. Bracts inconspicuous. Corolla $<11 \mathrm{~mm}$ long .

3'. Hermaphrodite, erect herbs or subshrubs, with alternate leaves. Flowers in an erect terminal thyrse, the cymes subtended by conspicuous red or purplish bracts. Corolla long-tubular, 20-35 mm long.

2. Amasonia

4. Calyx lobes spine-tipped, corolla orange, ca. $19 \mathrm{~mm}$ long. Stamens held just below, but not enclosed by, upper corolla lip. Introduced weed.

4'. Lobes not spine-tipped, corolla white or cream to lilac or pink, usually less than $10 \mathrm{~mm}$ long. Stamens at first held within and enclosed by hinged lower lip of corolla, and with a sudden release by pollinator (subtribe Hyptidinae).

5. Flowers \pm sessile in pedunculate globose or subglobose heads or capitula, surrounded by an involucre of bracteoles.

5'. Flowers never grouped in compact globose or subglobose heads or capitula. Flowers in lax or congested cymes, with inconspicuous bracteoles, or if bracteoles conspicuous and enclosing the cyme, never forming a compact globose head, and often in elongate, terminal thyrses, sometimes congested and spiciform., or in laxer few-flowered cymes on short peduncles from the axils of foliose bracts similar to the leaves

6. Herbs or subshrubs with flowers in compact capitula. Calyx lobes never reflexed in fruit. Corolla white with small vinous dots on upper lip. Nutlets ovoid or ellipsoid, rarely with a truncate apex. 4. Hyptis

6'. Viscid herb with flowers in pedunculate, rounded, but not compact heads. Calyx lobes deltate, spreading to reflexed in fruit. Corolla blue-violet, unspotted. Nutlets cymbiform, concave on inner face, with an involute, fimbriate margin.

6. Marsypianthes

7. Flowers in usually few-flowered cymes, either shortly pedunculate and with elliptic to ovate, often rigid and veined bracteoles partially enclosing them, and often forming a lax or congested elongate thyrse, or cymes sessile with bracteoles subulate, rigid, and inconspicuous, forming a slender, dense or partly interrupted spike. 3. Cantinoa

7'. Flowers in axillary, few-flowered shortly pedunculate cymes, in the axils of foliaceous bracts or in shortly cincinnate cymes, with bracteoles inconspicuous and often forming a terminal spiciform thyrse.

7. Mesosphaerum

1. Aegiphila Jacq., B.D. Jacks., Index Kew. 1(1): 46. 1893

Aegiphila (subfamily Ajugoideae) is a genus, of usually dioecious trees, shrubs or woody vines (Cantino in Harley et al. 2004; França 2003), with opposite leaves, often bearing nectarial glands on the lamina, and with typically 4-merous, usually small and cream-coloured flowers, gynoecium with style terminal, fruit drupaceous, ovoid, with persistent, cupulate calyx. The genus contains ca. 116 species, mostly Neotropical, with 32 species throughout Brazil (França 2003), occurring principally in forest or forest margins and in cerrado. 
Key to species of Aegiphila from the canga of Serra dos Carajás

1. Tree or shrub with elongate, oblanceolate leaves $15-33 \mathrm{~cm}$ long or more, ascending, leaf-base longattenuate into an indistinct petiole. Flowers in compact, sub-umbellate, many-flowered axillary cymes on peduncles $<1.5 \mathrm{~cm}$ long 1.1. Aegiphila integrifolia

1'. Scandent shrub or woody vine with broadly ovate-lanceolate to ovate-oblong leaves $8-15 \mathrm{~cm}$ long, leaf-base truncate to rounded. Flowers in a long sub-pyramidal thyrse $<20 \mathrm{~cm}$ long, of terminal and axillary sub-umbellate cymes on peduncles $1-7 \mathrm{~cm}$ long...... 1.2. Aegiphila racemosa

1.1. Aegiphila integrifolia (Jacq.) Moldenke, Brittonia 1: 337-338. $1934 . \quad$ Figs. 1a-d, 2a

Tree or shrub up to $3 \mathrm{~m}$ or more tall. Young stems densely off-white-tomentose with appressed hairs. Cauline leaves ascending, oblanceolate, apex acuminate, base narrowing from mid-lamina and long-attenuate into the indistinct petiole, lamina 15-33 × 5-11 cm, membranous, discolorous, with sessile glands, sparsely hairy above, with long, whitish hairs, more densely hairy beneath. Inflorescence of many-flowered, sub-umbellate, densely tomentose, pedunculate cymes, from axils of upper leaves, peduncles ca. $1.5 \mathrm{~cm}$ long, densely tomentose. Flowers with calyx ca. 4-6 mm long, tubular, densely appressed-hairy, corolla 8-11 $\mathrm{mm}$. Female flowers with exserted, filamentous style and long style-arms. Male flowers with longexserted stamens. Fruit ca. $8 \mathrm{~mm}$ long, ellipsoidoblong with persistent calyx forming a cupule.

Material selected: Canaã dos Carajás, Serra do Tarzan, $06^{\circ} 20^{\prime} 00^{\prime} \mathrm{S}, 50^{\circ} 09^{\prime} 31^{\prime \prime} \mathrm{W}, 721 \mathrm{~m}, 28 . \mathrm{III} .2015$, P.L. Viana et al. 5652 (MG). Parauapebas, N-4, mina piloto para exploração do ferro, 700 m, 15.III.1984, A.S.L. Silva et al. 1827 (MG); N5, $5 \mathrm{~km} \mathrm{~W}$ of AMZA camp, $06^{\circ} 04$ 'S, $50^{\circ} 10^{\prime} \mathrm{W}, 700-800 \mathrm{~m}, 15 . \mathrm{V} .1982$, C.R. Sperling et al. 5695 (MG); N7-N8, 27.III.2015, A. Cardoso et al. 1978 (MG); Próximo ao aeroporto, 23.XII.1988, J.P. Silva 242 (MG).

França \& Giulietti (2012) have provided the correct authority for the name of this species, which for long had been incorrectly assigned to B.D. Jackson.

A very frequent, widespread and variable forest species occurring from Panama and Trinidad and Tobago, southwards throughout most of South America, to Bolivia and Paraguay and in Brazil from Amapá and Acre to Rio Grande do Sul. Flowering from December to May. In the Serra dos Carajás it occurs in various areas of the Serra Norte and in the Serra do Tarzan, along forest margins.

1.2. Aegiphila racemosa Vellozo, Fl. Flumin.: 37. 1829.

Fig. 1e

Scandent shrub or liane to $6 \mathrm{~m}$ tall. Stems tomentose. Cauline leaves widely spreading from stem, broadly ovate-lanceolate to ovate-oblong, apex acuminate, base truncate to rounded, petiole 5-12 mm long, lamina $8-15 \times 3.2-7 \mathrm{~cm}$, slightly coriaceous, subglabrous above, adpressed-hairy below, with sessile glands. Synflorescence < $20 \mathrm{~cm}$ long, sub-pyramidal, of terminal and axillary sub-umbellate, many-flowered cymes, on peduncles $1-7 \mathrm{~cm}$ long, patent. Flowers with calyx 5-6 mm long, tubular, appressed-hairy, 4-lobed, lobes deltate, corolla 7-8 mm long; female flowers with exserted, filamentous style with 2 long style arms, stamens slightly exserted; male flowers not seen. Fruit 12-15 × 7-10 mm long, broadly ellipsoid to ellipsoid-oblong, smooth, glabrous, with persistent calyx forming a cupule.

Material selected: Parauapebas, Serra Norte, N1, estrada entre N1 e o Rio Itacaiunas, na beira da estrada, 02. VI.1986, M.P.M. Lima \& G.M. Barroso et al. 91 (MG); Estrada para N5, 25. I.1985, O.C. Nascimento \& R.P. Bahia 949 (MG); estrada para Itacaiunas, 31. I.1985, O.C. Nascimento \& R.P. Bahia 1081 (MG).

A specimen (C.M. Araújo 102) from the Serra dos Carajás, determined by França as Aegiphila vitelliniflora Walpers is cited by him from RB (França 2003). This taxon is considered to be closely related to $A$. racemosa (França 2003) and was placed in synonymy of Aegiphila racemosa by Sampaio \& Perckolt (1943). The characters used to separate the two species are not very convincing, and do not seem to justify treating them as distinct. However, I have not seen type material of either species, and have been so far unable to examine the material of $A$. vitelliniflora from Carajás in RB.

Widely distributed from Venezuela and the Guianas, to Amazonia and in cerrado and forest in Central-West and in Atlantic forests of NE and SE Brazil, South to Santa Catarina. Flowering: January and June. Serra dos Carajás: Serra Norte, $\mathrm{N}-1, \mathrm{~N}-5$. No material of this species has been collected from the Flora area since 1986.

\section{Amasonia L. f., Suppl. Pl. 48: 294. 1782.}

Amasonia (subfamily Ajugoideae) is a genus of erect scapose, rhizomatous shrubs or subshrubs (Cantino in Harley et al. 2004), 
with usually alternate sessile or subsessile leaves usually grouped together in mid-stem. Inflorescence an elongate thyrse with often brightly coloured red to purple bracts and long tubular, protandrous flowers, calyx red or purple, actinomorphic, 5-lobed; corolla tubular, yellow to white, weakly zygomorphic, 5-lobed, anterior lobe usually largest; stamens 4, didynamous, exserted, filaments curving downward after pollen shed. Fruit drupaceous. About six to

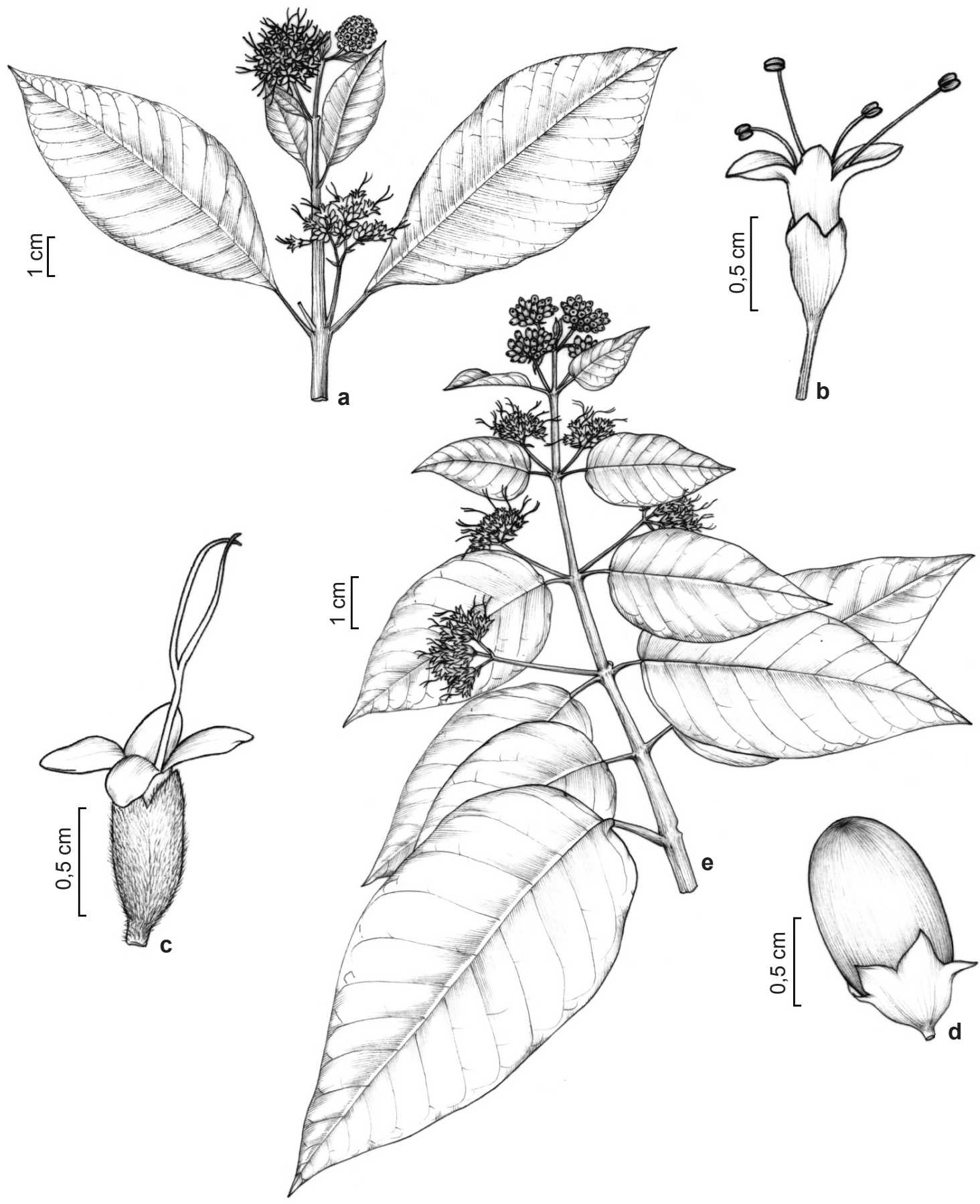

Figure 1 - a-d. Aegiphila integrifolia - a. leaves with inflorescences; b. male flower; c. female flower; d. fruit. e. Aegiphila racemosa - flowering branch. 
eight species in savanna and forest margins, Trinidad and $\mathrm{N}$ and $\mathrm{C}$ South America. The genus is taxonomically difficult, and various attempts have been made to resolve their classification (Moldenke 1939; Santos et al. 2012) However, the species recognized are very variable, and many of the diagnostic characters, used in the past, are unreliable. A detailed biosystematic study of the genus is needed. The descriptions are based entirely on material from Carajás.

Key to species of Amasonia from the canga of the Serra dos Carajás

1. Stems, leaves and bracts densely hairy, with patent or weakly curved trichomes

2.2. Amasonia hirta

1'. At least the upper surface of leaves subglabrous to thinly hairy, with curved, slightly adpressed trichomes.... 2

2. Leaves thinly membranous, upper surface rather dull green, often vinaceous beneath, glabrous or very sparsely hairy on both surfaces. Leaf margin entire or repand, or shallowly dentate, with rather few blunt teeth in upper half. 2.3. Amasonia lasiocaulos

2'. Leaves membranous or cartaceous, upper surface dark, bright green, usually rather sparsely hairy, with rigid, curved, slightly adpressed trichomes, lower surface pale green, never vinaceous, more sparsely hairy, with trichomes often confined to midrib and veins. Leaf margin distinctly serrate in distal half.

2.1. Amasonia campestris

2.1. Amasonia campestris (Aubl.) Moldenke, Torreya 34: 8. 1934.

Figs. 2b; 3a-c

Subshrub with a usually single, erect, unbranched stem $30-65 \mathrm{~cm}$ tall. Stems rather densely hairy, with rigid hairs. Leaves with lamina 6.5-11 $\times 2.2-4 \mathrm{~cm}$, shortly oblanceolate, oblanceolateovate to elliptic-lanceolate, with apex obtuse to acuminate, rounded and apiculate, base attenuate, margin distinctly serrate, lamina membranous, weakly discolorous, adaxial surface bright green, with impressed midrib and veins, sparsely to more often densely hairy with curved, rigid hairs, abaxial surface pale green, rather sparsely hairy with slender hairs especially on prominent midrib and veins and numerous minute sessile, sunken glands, patelliform glands very rarely present, petiole ca. $5-15 \mathrm{~mm}$ long,. Inflorescence axis (4-)7-11 cm long with scape 16-24 cm long, bracts subtending cymes ca $1-1.7 \mathrm{~cm}$ long, broadly elliptic, often toothed, red above, paler, often ochre beneath, sometimes with patelliform glands on abaxial surface. Flowers with calyx reddish, ca. ca. 9-11 mm long, lobes deltate, corolla ca. $2.8-3.0 \mathrm{~cm}$ long, pale yellow.

Material selected: Parauapebas, Serra Norte, Floresta Nacional de Carajás, Lagoa do N1, 06 $011^{\prime} 31.8^{\prime \prime}$ 'S, 50 ${ }^{\circ} 16^{\prime}$ 33.2" W, 676 m, 29.III.2015. R.M. Harley et al. 57136 (MG); N2, $06^{\circ} 02^{\prime} 02^{\prime \prime} \mathrm{S}, 50^{\circ} 17^{\prime} 06^{\prime \prime} \mathrm{W}, 710 \mathrm{~m}, 23 . I I .2016$. R.M. Harley et al. 57363 (MG); N3, 14.III.1985, R.S. Secco et al. $454(\mathrm{MG})$; N4, mina piloto para a exploração de ferro, 700-750 m, 15.III.1983. A.S.L. Silva et al. 1813 (MG); Serra Norte, Trilha da Lagoa da Mata, $06^{\circ}$ 02'28.5"S, 5005'15.1'W, 667 m, 25.III.2016. R.M. Harley et al. 57481 (MG). (Marabá): Caminho para o Azul, 03.IV.1977, M.G. Silva \& R. Bahia 3032 (MG).
Widely distributed from Venezuela and the Guianas, to Amazonia and NE Brazil to Espírito Santo and extending to Goiás and Mato Grosso. Growing especially in cerrado and forest margins. Flowering: February to May, fruiting unknown. In Serra dos Carajás only recorded from the Serra Norte.

2.2. Amasonia hirta Benth., Ann. Nat. Hist. 2: 451 . 1839.

Fig. 3d-f

Densely hairy subshrub to $1 \mathrm{~m}$ tall with erect unbranched, pink-tinged stem. Stem very densely hairy with long, patent to weakly antrorse, sometimes red or yellowish-brown to white hairs. Cauline leaves $8.0-16.0 \times 3.0-5.5 \mathrm{~cm}$, often loosely clustered on stem. Lamina oblanceolate, discolorous, adaxial surface darker green, apex broadly obtuse to rotund, sometimes apiculate, with base long-attenuate in basal $2 / 3$ of lamina, with petiole indistinct, upper surface densely hairy, with long, yellowish to whitish patent hairs or weakly curved trichomes, and many small pale sessile glands, lower surface as upper, but sessile glands more numerous, sunken and darker, patelliform glands not observed, margin dentate-serrate along upper $1 / 3$ of leaf margin, entire to very sparsely toothed towards base. Inflorescence elongate $<$ $15 \mathrm{~cm}$ long, with, along stem just just below, few, small, narrow bract-like leaves often present. Bracts slender, narrowly elliptic, pale red on adaxial surface, densely long-hairy especially on adaxial surface, patelliform glands sparse to abundant on both sides. Calyx ca. $11 \mathrm{~mm}$ long, lobes ca. $5 \mathrm{~mm}$ 
long, pale pinkish red, very densely hairy, corolla pale yellow, ca. $27 \mathrm{~mm}$ long, often slightly reddishtinged, without markings, very densely long-hairy externally, on base of lobes and upper part of tube. Fruit (immature?) dark green, $8-10 \times$ ca. $6 \mathrm{~mm}$.

Material selected: Parauapebas, FLONA de Carajás, Serra Norte N1, 0602'23" S, 50¹6'44”'W, 690 m, 26.III.2015, P.L. Viana et al. 5610 (MG); Serra dos Carajás, Platô, 0600'S, 50¹8’W, 700 m, 23.V.1969. P. Cavalcante 2139 (MG).

Widely distributed from Pará and Amazonas southwards to Mato Grosso, Goiás and the Distrito Federal, to Minas Gerais, São Paulo and Eastern Paraguay, especially in cerrado, forest margins and less shaded forest understorey. Flowering from March to May. In Serra dos Carajás only recorded from the Serra Norte.
2.3. Amasonia lasiocaulos Mart. \& Schau. ex Schau., in A. DC. Prodr. 11: 678. 1847.

Figs. 2c; 3g-i

Subshrub with a usually single, erect, unbranched stem to ca. $70 \mathrm{~cm}$ tall. Stems thinly to rather densely hairy, with slender, rigid hairs. Leaves with lamina (12-)17-26 × 3-5.5 cm, oblanceolate, with apex obtuse to acute or apiculate, base narrowly attenuate \& indistinctly narrowing into thickened petiole, margin repand, especially in lower part of leaf, to weakly and very shallowly dentate-serrate, lamina thinly membranous, plane, discolorous, adaxial surface dark green, glabrous or with sparsely scattered short, curved and broad-based, rigid hairs, midrib and veins weakly impressed, abaxial surface paler, greyish-green,
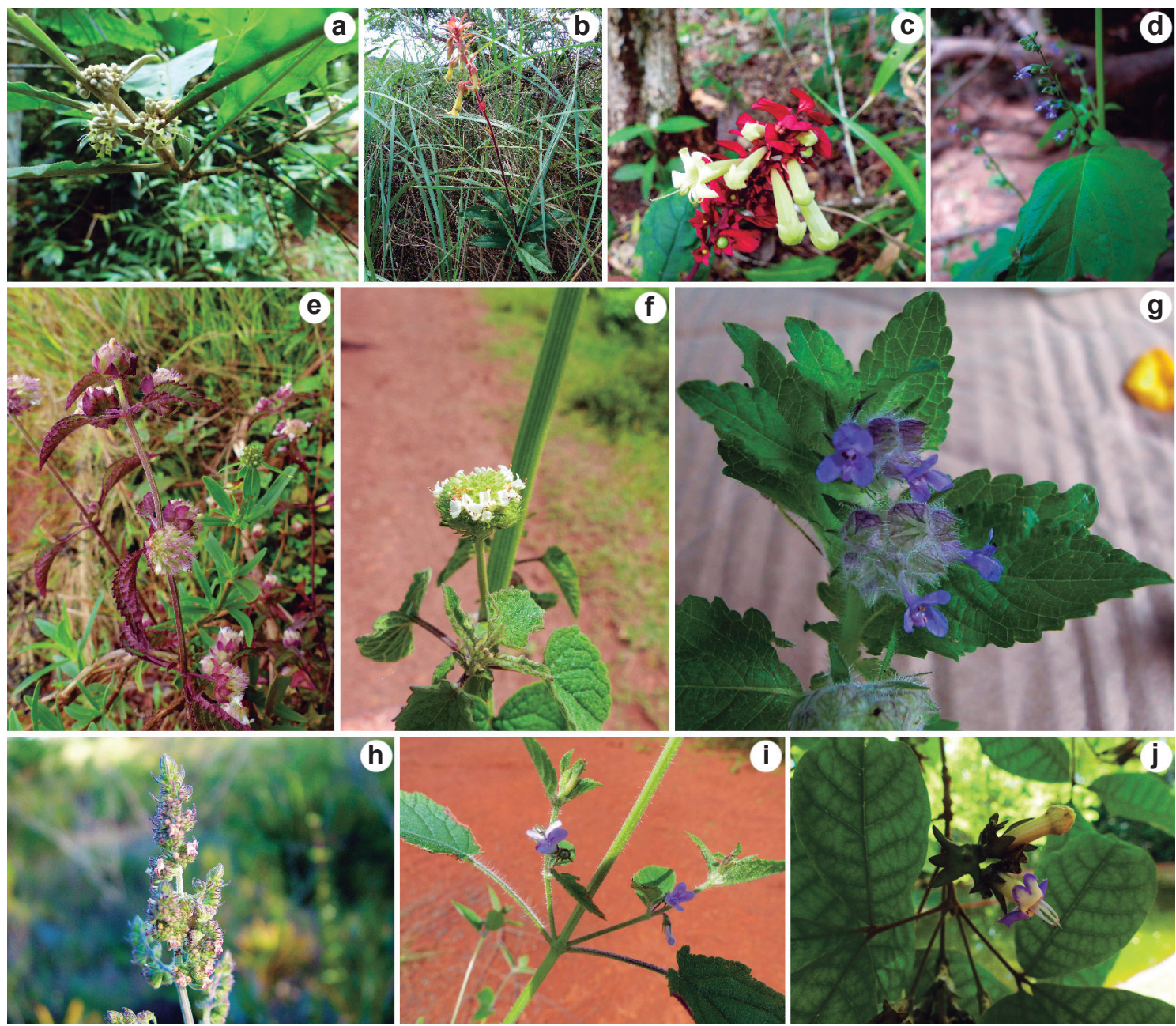

Figure 2 - a. Aegiphila integrifolia; b. Amasonia campestris; c. Amasonia lasiocaulos; d. Cantinoa mutabilis; e. Hyptis atrorubens; f. Hyptis recurvata; g. Marsypianthes chamaedrys; h. Mesosphaerum pectinatum; i. Mesosphaerum suaveolens; j. Vitex triflora. 
often purple-tinged, glabrous or very sparsely hairy, often densely so along nerves and midrib, and with many very small, sunken glands, patelliform glands very rarely present, nerves prominent, with, midrib thickened, $1-1.5 \mathrm{~mm}$ diam., petiole $0-2$ $\mathrm{mm}$ long, thickened. Inflorescence axis 9-25 cm long with scape $12-28 \mathrm{~cm}$ long, with a few, narrow bract-like leaves below, bracts subtending cymes ca 2-3 cm long, ovate to broadly lanceolate, often entire, red above, paler beneath, sometimes with patelliform glands on abaxial surface. Flowers with calyx reddish, ca. 7-10 $\mathrm{mm}$ long, lobes deltate, rather hairy especially toward base, corolla ca. 2.8-3.4 cm long, pale yellow or greenish cream. Fruit not seen.

Material selected: Canaã dos Carajás, Serra Tarzan, 06²0'00'S, 5009'31''W,721 m, 28.III.2015, P.L. Viana et al. 5670 (MG). Parauapebas, Serra Norte, N1, 0602'30'S, 50¹6'14''W, 705 m, 26.III.2015, P.L. Viana et al. $5573(\mathrm{MG})$; N4, Nova Usina 130, 0601'58'S, 50॰09'24"'W, 25.IV.2009, V.T. Giorni et al. 237 (BHCB); N4W Sul, 0604'22'S, 50¹1'42”'W, 505 m, 24.III.2012, P.B. Meyer et al. 1198 (BHCB); Serra Norte, Km 134, 14.V.1982, R. Secco et al. 170 (MG); Serra dos Carajás, no platô, $06^{\circ} 00^{\prime} \mathrm{S}, 50^{\circ} 18^{\prime} \mathrm{W}, 700 \mathrm{~m}, 26 . \mathrm{V} .1969, P$. Cavalcante 2184 (MG); Serra dos Carajás, regeneração próximo ao aeroporto, 28.I.1985, O.C. Nascimento \& R.P. Bahia 1034 (MG); Serra dos Carajás, 23.IV.1985, N.A. Rosa et al. 4700 (MG); Estrada para a Serra dos Carajás, Km 3, 25.III.1977, M.C. Silva 2864 (K, MG). Serra do Rabo (Bocaina), 06¹8'36"S, 4953'22”W, 692 m, 14.XII.2007, N.F.O Mota et al. 1190 (BHCB).

The most frequent species in Carajás, it can be recognized by its usually larger, dull green subglabrous leaves and very conspicuous bracts, which are larger and more brightly coloured than in the other two species.

The species is widely distributed in Northern and Western South America from Peru, Colombia and Venezuela and the Guianas, through Amazonian Brazil, from Acre to Amapá and Pará, Maranhão, Tocantins and Ceará, and South into Mato Grosso, in cerrado and savanna/forest margins. Flowering from December to May. In the Serra dos Carajás recorded from the Serra do Tarzan, Serra Norte and Serra da Bocaina.

3. Cantinoa Harley \& J.F.B. Pastore, Phytotaxa 58: 8. 2012.

= Hyptis sect. Spicaria Benth. (1833). = Hyptis sect. Polydesmia Benth. (1833) pro parte.

Cantinoa is a genus belonging to subfamily Nepetoideae, tribe Ocimeae subtribe Hyptidinae, composed of herbs or subshrubs with mesomorphic leaves; flowers borne in 12-26-flowered \pm ovoid cymules, flowers subsessile, surrounded by slender, ovate to linear, rigid or scarious bracteoles, sometimes investing the flowers to form a small involucre. Cymules often clustered into terminal spikes, or forming branched panicles. Flowers with gynoecium without a stylopodium, fruit of four nutlets, ovoid to narrowly ellipsoid. Twentyfive species occur in Tropical America, from the southern United States to Argentina and the Caribbean, 23 in Brazil, most in cerrado, campo or forest margins.

\section{Key to species of Cantinoa from the canga of the Serra dos Carajás}

1. Strongly aromatic herb. Inflorescence a compact terminal, or axillary spiciform thyrse, cymules subsessile and congested, with bracts inconspicuous and with subulate bracteoles. Leaves with lamina 4.8-11.5 × 1.4-3.6 cm, lanceolate, with base long-attenuate 3.1. Cantinoa americana

1'. Very weakly aromatic herb. Inflorescence terminal, branched, a slender, elongate, interrupted thyrse with small, few-flowered cymules, invested by an involucre of veined bracteoles and on peduncles 2-5 $\mathrm{mm}$ long, from axils of small, foliose bracts. Leaves with lamina 6.5-8 $\times 2.4-5.0 \mathrm{~cm}$, ovate-rhomboid, with base broadly cuneate to truncate and abruptly attenuate into petiole 3.2. Cantinoa mutabilis

3.1. Cantinoa americana (Aubl.) Harley \& J.F.B. Pastore, Phytotaxa 58: 9. 2012.

= Hyptis spicigera Lam. (1789).

Annual herbs, 0.5-2 m tall, aromatic, stems erect, quadrangular, ca. 3-4 mm diam., with retrorse prickles on angles, subglabrous except at nodes, with sessile and stipitate glands, becoming hairier in inflorescence with short, broad-based, whitish hairs. Cauline leaves with petiole $(1.7-7.8 \mathrm{~cm}$; lamina $4.8-$ $11.5 \times 1.4-3.6 \mathrm{~cm}$, lanceolate, membranous, pale green, apex acute, base attenuate, margin irregularly serrate, adaxial surface subglabrous, abaxial surface pilose, and with dense sessile glands. Inflorescence a compact terminal, or axillary spiciform thyrse $4.0-8 \times 0.7-1.2 \mathrm{~cm}$, 
simple or branched, lower verticils sometimes remote, cymes subsessile with inconspicuous bracts; bracteoles $3.5-4 \mathrm{~mm}$ long, subulate, long-ciliate, calyx at anthesis $2.7-3.5 \mathrm{~mm}$ long, tube infundibuliform, lobes $1.5-2 \mathrm{~mm}$, subulate, long-ciliate especially below, calyx in fruit 6-7 $\mathrm{mm}$ long, cylindrical, externally sparsely hairy above, with dense, sessile glands, internally shortly hairy in upper half, lobes long, rigid, subulate, long-ciliate; corolla bluish-lilac or white, tube (3-4 mm long, with short upper lip; gynoecium without stylopodium. Nutlets 1.3-1.5 mm long, smooth, rounded, weakly trigonous, pale brown.
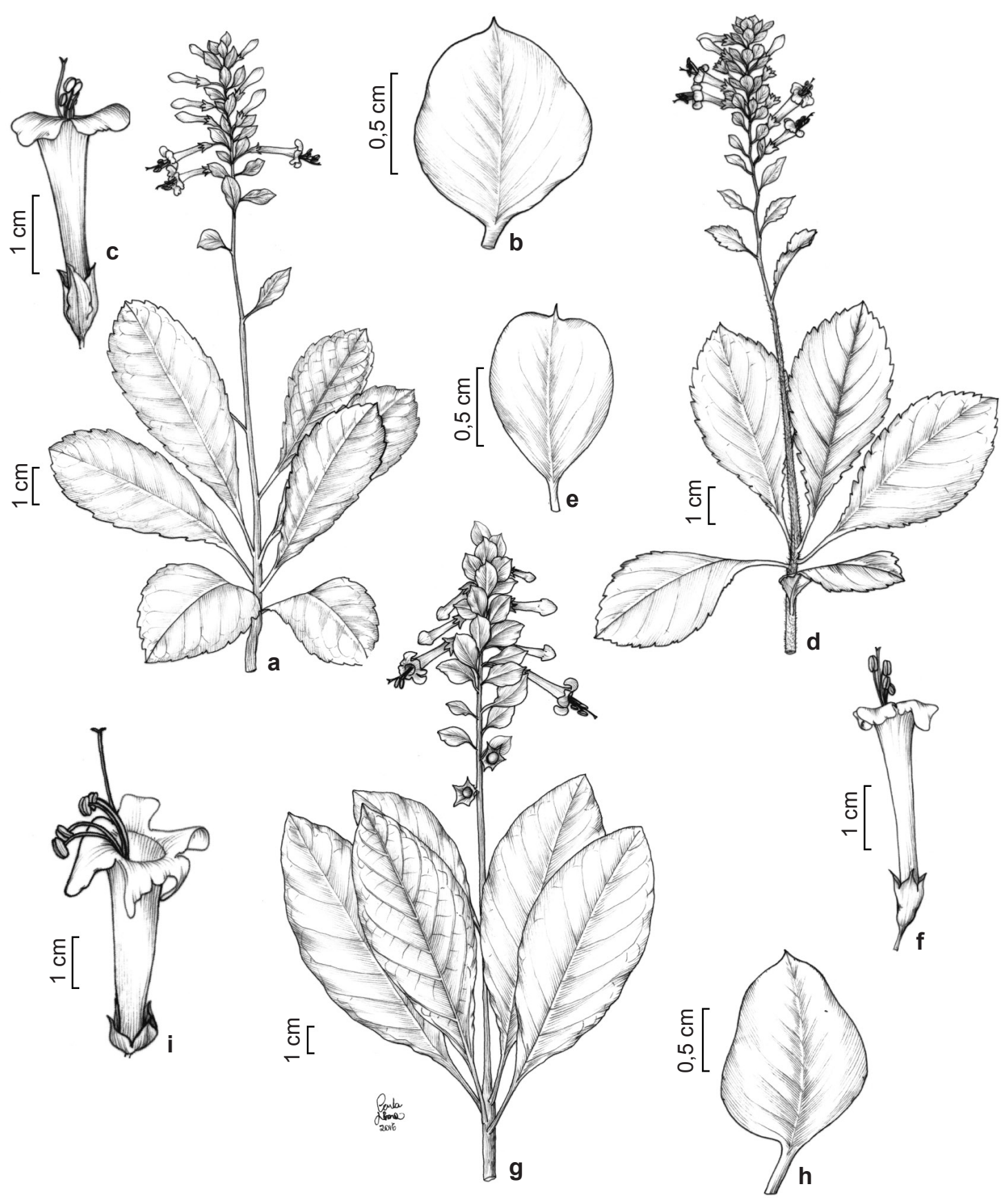

Figure 3 - a-c. Amasonia campestris - a. habit; b. bract; c. flower. d-f. Amasonia hirta - d. habit; e. bract; f. flower. g-i. Amasonia lasiocaulos - g. habit; h. bract; i. flower. 
Material selected: Canaã dos Carajás, Serra da Bocaina, 06¹7'46” S, 49॰54'34'”W, 742 m alt., 10. III. 2012. A.J. Arruda 680 (BHCB); Parauapebas, Serra Norte, antigo alojamento da Estacom, Km 13, 25. IV. 1989. J.A.A. Bastos 189 (MG, HCJS).

Widespread as a weed of cultivation and on roadsides, almost throughout Tropical America and introduced as a weed in the Old World tropics. In Brazil widespread in Amazonia from Acre, Amazonas to Pará and South to São Paulo, and certainly more frequent than records indicate. Flowering from March to April. In the Serra dos Carajás recorded from the Serra Norte and the Serra da Bocaina.

3.2. Cantinoa mutabilis (Rich.) Harley \& J.F.B. Pastore, Phytotaxa 58: 10. 2012.

= Hyptis mutabilis (Rich.) Briq.(1896).

Fig. 2d; 4a-c

Short-lived perennial herb 1-2 $\mathrm{m}$ high, stems erect, branched, quadrangular, $<4 \mathrm{~mm}$ diam., with minute antrorse prickles on stem angles, internodes glabrous or very sparsely hairy above, with small, retrorse, curved hairs. Cauline leaves with petiole $2-4 \mathrm{~cm}$ long, lamina $6.5-8 \times 2.4-50$ $\mathrm{cm}$, ovate-rhomboid, membranous, apex acute or shortly acuminate, base broadly cuneate to truncate and abruptly attenuate into petiole, margin doubly and irregularly serrate, discolorous, paler green beneath, upper surface glabrous to sparsely pilose along midrib and at margin, with many sessile glands, lower surface subglabrous, hairier on midrib, and nerves, and with sunken, sessile glands. Inflorescence terminal, branched, a slender, elongate, interrupted thyrse, $<60 \mathrm{~cm}$ long, with small, few-flowered cymules, on peduncles 2-5 $\mathrm{mm}$ long, from axils of small, foliose bracts.

Material selected: Canaã dos Carajás, Serra do Tarzan, 06²2'15"S, 5006'58'W, 284m, 16.VI.2012, L.V. Silva et al. 1230 (BHCB); Serra do Tarzan, subida para a serra 06²5'19'S, 5005'48'W, 16.VI.2012, R.M. Harley et al. $57320(\mathrm{MG})$; Parauapebas, Serra da Bocaina, $06^{\circ} 18^{\prime}$ S, 49 $54^{\prime} \mathrm{W}, 18$. XII.2010, N.F.O. Mota et al.
1973 (MG, IAN, BHCB); Serra dos Carajás, margem da estrada para o Rio Itacaiunas, 01.VIII.1984, N.A. Rosa et al. 4658 (IAN, MG).

The description here is based on Mota 1973 (IAN), except for the reproductive characters at anthesis, which were not available on this specimen. Most material in Pará state can be referred to Hyptis rostrata Benth. (1833), which Briquet (1897) reduced to varietal status as Hyptis mutabilis var. rostrata (Benth.) Briq. It is a subglabrous form with membranous long-petiolate leaves, pedunculate few-flowered cymules, with calyces, which elongate greatly in fruit. Further study is needed to see if it merits recognition and transferral under Cantinoa.

The species is widespread in the New World Tropics and subtropics, from the Southern United States, the Caribbean and south to Argentina. Occasionally introduced in the Old World Tropics, and occurring in a wide variety of habitats. Flowering from June to December. In the Serra dos Carajás recorded from the Serra Norte and the Serra do Tarzan.

\section{Hyptis Jacq., Collectanea 1: 101, 103. 1787.}

Annual or perennial herbs or shrubs, belonging to subfamily Nepetoideae tribe Ocimeae subtribe Hyptidinae, with flowers in pedunculate to sessile, spherical or hemispherical capitula with an involucre of ligulate to ovate or filiform bracteoles, borne singly in the axils of foliaceous or reduced bracts and sometimes forming complex synflorescences. Flowers small, with cylindrical calyx, sometimes with tube deflexed below throat, corolla small, white, gynoecium with or without stylopodium. Fruit of 4 nutlets, ovoid to narrowly ellipsoid. The genus has recently been subdivided into a number of genera (Harley \& Pastore 2012), and now consists of ca. 144 species, in tropical and subtropical America, of which ca. 120 species occur in Brazil. A few species extend into the Old World tropics, usually as introduced weeds.

\section{Key to species of Hyptis from the canga of the Serra dos Carajás}

1. Fruiting calyx with tube strongly deflexed below throat; involucral bracteoles filiform.

1'. Fruiting calyx with tube straight; involucral bracteoles broader 4.4. Hyptis recurvata

2'. Calyx lobes setaceous. 4.3. Hyptis parkeri

3. Calyx lobes with broad, truncate sinus between them; involucral bracts ovate, not reflexed in fruit. Style jointed above nutlets, with persistent base to style (stylopodium).

3'. Calyx lobes with narrow sinus; involucral bracts narrowly lanceolate to linear, reflexed in fruit. Style not jointed, dehiscing at base (stylopodium absent). 4.2. Hyptis brevipes 
4.1. Hyptis atrorubens Poit., Ann. Mus. Par. 7: 466, t. 27 fig. 3. 1806.

Figs. 2e; 4d-e

Perennial herb, often reddish-tinged, stems decumbent to erect, often stoloniferous and rooting at nodes, thinly hairy with long, patent hairs. Cauline leaves with petiole $4-10 \mathrm{~mm}$ long, lamina $11-35 \times 8-20 \mathrm{~mm}$, broadly ovate to lanceolate, thinly membranous, apex acute, base truncate to long-attenuate, margin crenate-serrate. Inflorescence of pedunculate, capitula, borne singly in axils of foliaceous bracts, peduncles $1.3-3.5 \mathrm{~cm}$ long, capitula \pm hemispherical $1-1.4 \mathrm{~cm}$ diam., surrounded by involucre of ovate bracteoles, spreading at first, later appressed to flowers, outer 6-8 $\times 3-4 \mathrm{~mm}$, often reddish-tinged, calyx at anthesis 3-4 mm long, in fruit 6.5-9 mm long, lobes $1.5-2 \mathrm{~mm}$ long, finely subulate, sinus between lobes broadly truncate; corolla white, $4.5-5 \mathrm{~mm}$ long with pink spots on lobes; gynoecium with stylopodium narrowly conical, long-overtopping ovary. Nutlets $0.75-1 \times 0.5-0.7 \mathrm{~mm}$, ovoid.

Material selected: Canaã dos Carajás, Serra do Tarzan, no platô, $06^{\circ} 04^{\prime} 01^{\prime \prime}$ S, 5007'46”'W, 751, 28.III.2015, R.M. Harley et al. 57114 (MG); Serra Sul, S11 B, $06^{\circ} 20^{\prime} 35^{\prime}$ 'S, $50^{\circ} 25^{\prime} 28^{\prime \prime} \mathrm{W}, 820 \mathrm{~m}, 19 . \mathrm{V} .2010$, M.O. Pivari et al. 1534 (BHCB); S11D. No alto da cachoeira, 06²4'9”'S, 50²0'34”'W, 11.IV.2011, L. Tyski 192 (HCJS); S11D, segundo aceiro a direita da área da Pilha de Esteril, 06 27'11'S, 50²0'17” W, 10.XII.2012, I.M.C. Rodrigues et al. 586 (BHCB). Parauapebas, Serra Norte, N1, 06 00'49”S, 50 $17^{\circ} 51$ ” W, 683 m, 19.IV.2012, A.J. Arruda et al. 929 (BHCB, MG); N1, 0602'04”'S, 50¹7'13”'W, 694 m, 29.III,2015, R.M. Harley et al. 57124 (MG); N5, acesso a Casa da Colina, canga, 20.IV.1989, J.P. Silva 454 (HCJS); Núcleo de Carajás, Linha da Transmissão, $06^{\circ} 03^{\prime} 10.3$ "S, 5004'46.2" W, 13.V.2010, L.Tyski 662 (HCJS).

The species is usually easily recognized by the procumbent to ascending habit, the axillary, rather shortly pedunculate flower heads with broad, appressed involucral bracts, distinctly pinnately nerved, contrasting with the very finely subulate calyx lobes separated by truncate sinuses, and white, pink-spotted flowers. Specimens from Pará, especially from the Flora area, show remarkable morphological diversity. Plants occurring along forest tracks or in shade, especially those not growing on canga, are greener and more robust than those occurring directly on open-site canga, which are often dwarfed and brightly tinged reddish. The forest form corresponds morphologically to Hyptis atrorubens var. africana Epling (1936c), from Sierra Leone, which is a more robust form with larger leaves, but intermediates occur in the Flora area.
Widely distributed from Mexico and the Caribbean, south to Peru, Bolivia and Brazil, also in West Africa. Throughout most of tropical Brazil, south to São Paulo. Damp savanna, and open grassy places, damp forest margins and by water, often frequent in dried up lakes over canga. It is characteristic of coastal savanna in the southern part of its range. Flowering and fruiting throughout the year. In the Serra dos Carajás recorded from the Serra Norte, Serra do Tarzan and Serra Sul.

4.2. Hyptis brevipes Poit., Annales du Muséum d'Histoire Naturelle Paris 7: 465. 1806.

Fig. 4f-g

Slender perennial herb, rarely reddish-tinged, stems erect, subglabrous with appressed hairs, on angles. Cauline leaves with petiole $0.6-1.5 \mathrm{~cm}$, merging into lamina, lamina (4-)6-9 × 2-3.2 cm, elliptic-lanceolate to weakly rhomboid, green, apex acute, base narrowly attenuate, decurrent onto petiole, margin coarsely and irregularly serratedentate or weakly lobed, subglabrous except for adpressed hairs along midrib and leaf-margin, and short, sparse, conical hairs on adaxial surface. Inflorescence of pedunculate capitula, from axils of foliaceous bracts, peduncles slender, hairy, $<1$ $\mathrm{cm}$ long. Capitula \pm spherical, pale green, $6-8 \mathrm{~cm}$ diam., with involucre of membranous, narrowly lanceolate bracteoles 7-9 × 1-1.5 mm, becoming reflexed in fruit. Flowers with long white hairs at base, calyx at anthesis ca. $3.2 \mathrm{~mm}$ long, $5 \mathrm{~mm}$ long in fruit, tube membranous, straight, calyx lobes subequal, 1.7-2 mm long, setaceous, corolla white or pink-tinged, tube ca. $3.5 \mathrm{~mm}$ long. Nutlets $0.8-1$ $\times 0.3-1.4 \mathrm{~mm}$, narrowly oblong-elliptic, black, verruculate, glabrous, abscission scar whitish.

Material selected: Canaã dos Carajás, Serra do Tarzan, estrada para a serra. $06^{\circ} 19^{\prime} 44^{\prime \prime} \mathrm{S}, 50^{\circ} 08^{\prime} 20^{\prime \prime} \mathrm{W}, 763 \mathrm{~m}$, 01.V.2015, N.F.O. Mota et al. 3016 (MG). Parauapebas, Serra da Bocaina (Serra do Rabo), 06 $18^{\circ} 54^{\prime}$ 'S, 49 $54^{\prime} 35^{\prime \prime} \mathrm{W}$, 707 m, 15.XII.2010, N.F.O. Mota et al. 1858 (BHCB).

This species is easily recognized from others in the area due to its erect, more or less glabrous habit, lanceolate-attenuate leaves, the capitulum with an involucre of narrowly lanceolate bracteoles, and flowers with a straight calyx-tube and slender sub-equal, somewhat setaceous lobes, with a narrow sinus between them. The description is based on only two, remarkably similar collections from Carajás, which are atypical for this species, with trichomes mostly appressed, and cauline leaves relatively broad. It is an unusual biotype, known only from the Flora area, and further collections are much needed. 

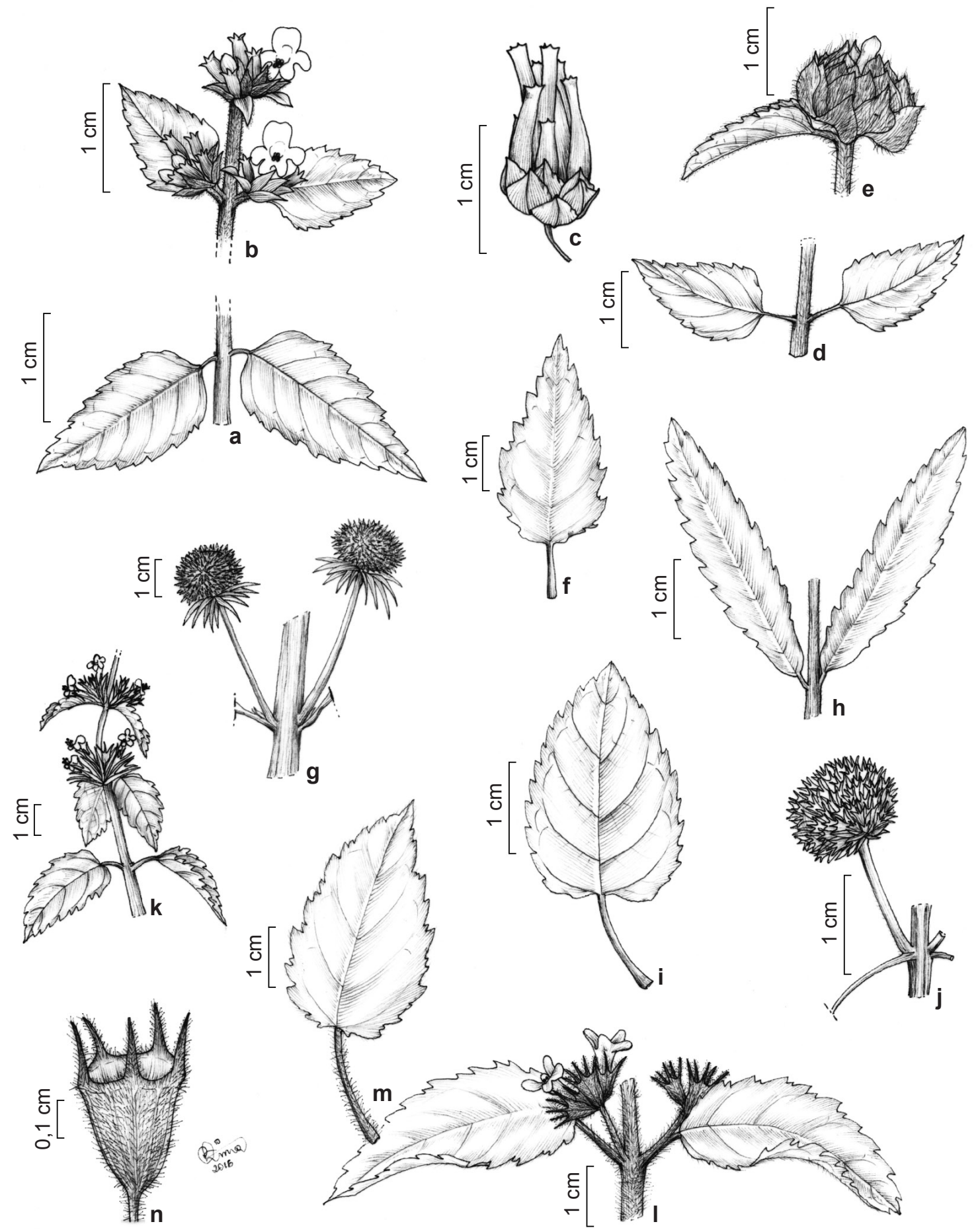

Figure 4 - a-c. Cantinoa mutabilis - a. cauline leaves; b. part of inflorescence; c. fruiting cyme with bracteoles. d-e. Hyptis atrorubens - d. cauline leaves; e. capitulum. f-g. Hyptis brevipes - f. cauline leaves; g. pedunculate capitula. h. Hyptis parkeri - cauline leaves. i-j. Hyptis recurvata - i. cauline leaf; j. capitulum. k. Mesosphaerum pectinatum - part of inflorescence. 1-n. Mesosphaerum suaveolens - 1. part of inflorescence; m. cauline leaf; n. fruiting calyx. 
The species is widespread from México and the Caribbean, south to Peru, Paraguay and Argentina, and is also introduced into the Palaeotropics as a weed. It occurs throughout much of Brazil, but is infrequent or absent in some southern states. Frequent on damp roadsides, in forest and in open areas, and by water. Flowering and fruiting from April to December. In the Serra dos Carajas, it has so far only been recorded in the eastern outlying mountains of the Serra do Tarzan and the Serra da Bocaina. It has also been observed, in a very desiccated state, at the base of the Serra da Bocaina, in a disturbed area, at an altitude of $159 \mathrm{~m}$.

4.3. Hyptis parkeri Benth., Labiat. Gen et Spec. 108. 1833.

Fig. $4 \mathrm{~h}$

Perennial, subglabrous herb, often tinged red, stems decumbent to erect $<25-60 \mathrm{~cm}$. Lower stems rooting at nodes. Cauline leaves $20-0(-57) \times 7-14$ $(-16) \mathrm{mm}$, broadly elliptic to elliptic-lanceolate, membranous, with sessile glands; base rounded to truncate, apex acute, margin serrate; petiole $1-2 \mathrm{~mm}$ long. Inflorescence of few, pedunculate capitula from axils of upper leaves; peduncles 1-4.5 cm long, distally densely hairy; capitula $8-12 \mathrm{~mm}$ diam., hemispherical, involucral bracteoles 3-6 $\mathrm{mm}$ long. Flowers interspersed with long, whitish hairs; calyx at anthesis 3-3.5 mm long, ca. $5 \mathrm{~mm}$ long in fruit, greenish-white, with sessile glands, calyx lobes $<1 \mathrm{~mm}$ long, broadly deltate, obtuse, corolla white with pinkish dots on upper lip, tube $3.5 \mathrm{~mm}$ long, Nutlets $1.25 \times 0.7 \mathrm{~mm}$, oblong, , glabrous, with abruptly truncate apex, coronate with raised emarginate margin, base surrounded by pale swollen areas.

Material selected: Canaã dos Carajás, Serra do Tarzan, 06 19'14"S, 5005'58'W, 750 m, 15.XII.2007, Viana, P.L. et al. 3453 (HUEFS, BHCB). Parauapebas, N4, platô, 15.I.2010, L.C.B. Lobato et al. 3826 (MG); N4WS, 0606’36”'S, 50¹1'11'"W, 675 m, 23.IV.2012, A.J. Arruda et al. 1056 (BHCB); N5, margem do lago barragem $\mathrm{E}$. Sul, 31.X.1985, R. Secco \& O.C. Nascimento 695 (MG); N5, $6 \mathrm{~km} \mathrm{NE}$ of AMZA camp, $06^{\circ} 03^{\prime} \mathrm{S}, 50^{\circ} 06^{\prime} \mathrm{W}, 650 \mathrm{~m}$, 21.VI.1982, C.R. Sperling et al. 6264 (MG).

The species is easily recognized by its rather small capitula, with spreading, ligulate bracteoles and glabrous calyx, which has broadly deltate lobes. The nutlets have an unusual morphology with an apical coronate appendage, probably enabling dispersal by flotation. Plants with shorter, broader leaves, have been separated as Hyptis parkeri var. verbenifolia (Mart. ex Schmidt) Epling, but intermediates forms are frequent and scattered through the range.
A species of the Amazon basin, occurring in the states of Amapá, Amazonas, Pará, Rondônia, Roraima, also Maranhão and Northern Mato Grosso, and extending into Guyana, Venezuela, Colombia and Bolivia. Usually terrestrial, occurring in open areas subject to seasonal flooding, or in permanently wet areas. Flowering and fruiting from October to June. In the Serra dos Carajás the species is recorded from the Serra Norte and also further East in the Serra do Tarzan. In the Flora area, it often occurs in shallow lakes, which are without water during the dry season. H. parkeri often forms dense stands, which are submerged early in the year, developing and coming into flower when the soil dries out. It can frequently be found with Melochia sp. (Malvaceae).

4.4. Hyptis recurvata Poit., Ann. Mus. Hist. Nat. Par. 7: 467, t. 28. 1806.

Fig. 2f; 4i-j

Perennial herbs, $0.3-1.5 \mathrm{~m}$ tall, stems erect, often purple-tinged, subglabrous to thinly hairy, with shortly stipitate glands. Cauline leaves green or purple-tinged, glabrous to sparsely villous, petiole $0.7-3(-4.5) \mathrm{cm}$ long, lamina $2-4.5 \times$ $1.5-3 \mathrm{~cm}$, broadly ovate to ovate-lanceolate, membranous, apex acute, base cuneate, to cordate, margin serrate, Inflorescence a lax, elongate, often unbranched, raceme-like thyrse of pedunculate capitula, from axils of leafy bracts, peduncles 1.2-4 $\mathrm{cm}$ long, capitula $0.8-1.2 \mathrm{~cm}$ diam. at anthesis, to $1.5 \mathrm{~cm}$ diam. in fruit, \pm spherical at maturity, involucral bracteoles filiform. Flowers with calyx $2.5-3 \mathrm{~mm}$ long at anthesis, $4.8-5 \mathrm{~mm}$ in fruit, tube \pm cylindrical, becoming strongly deflexed below throat, densely hairy with short, patent hairs on upper, side of tube, calyx mouth oblique, lobes $1.0-1.3 \mathrm{~mm}$ long, subulate, corolla $3-3.5 \mathrm{~mm}$ long, white. Nutlets $0.6-0.75 \times 0.4 \mathrm{~mm}$, oblong-ellipsoid, mucilaginous when wet.

Material selected: Parauapebas, Serra Norte, N1, 06 00 '49”'S, 50¹7'00”'W, 25. VII. 2012, A.J. Arruda et al. 1253 (BHCB); Serra da Bocaina, $06^{\circ} 18^{\prime} 54^{\prime \prime} \mathrm{S}$, 4954'41”W, $700 \mathrm{~m}$ alt., 15.XII.2010, L.V.C. Silva et al. 1047 (BHCB); Serra da Bocaina, na beira da estrada, descendo da serra, na direção a Cederi, $644 \mathrm{~m}$, $06^{\circ} 18^{\prime} 38^{\prime \prime}$ 'S, 4952'20”'W, 24.VI.2015, R.M. Harley et al. 57292 (MG).

Hyptis recurvata is easily recognized by the strongly down-curved calyx tube, especially conspicuous in fruit.

The species occurs from Trinidad and Southern Mexico to Bolivia, Brazil and Northern Argentina. In Brazil, it is frequent through much of the country, from Amazonia, southwards through 
NE and CW Brazil to São Paulo (Harley 1983). It is found in open, usually wet savanna or by water. Flowering and fruiting throughout much of the year. At present, only recorded from the Serra dos Carajás in the Serra Norte and in the Serra da Bocaina.

4. Leonotis (Pers.) R.Br., in W.T. Aiton, Hort. Kew ed. 2, 3: 409. 1811 .

Tall herbs or shrubs, belonging to subfamily Lamioideae, native to the Old World, with leaves simple, often toothed, inflorescence thyrsoid, the cymes often in globose verticillasters, bracteoles spiny. Flowers large, calyx zygomorphic, 8-10 lobed, usually spinescent; corolla strongly two lipped, posterior lip longer, hooded, densely pubescent externally, stamens held under upper lip, lower lip small, soon withering, gynoecium with gynobasic style, without a stylopodium, fruit of four nutlets, oblong-trigonous, apex obliquely truncate. 10 species in the palaeo-tropics, this one a pantropical weed.

5.1. Leonotis nepetifolia (L.) R.Br. in W.T. Aiton, Hort. Kew, ed. 2, 3: 409. 1811.

Robust annual or short-lived perennial herb 1-3 m. tall. Leaves green; petiole $3-5 \mathrm{~cm}$, lamina 7-9 $\times$ 4-7.5 cm, broadly ovate, apex acute, base truncate to cordate and narrowly attenuate along petiole, margins deeply crenate, upper surface glabrous, thinly tomentose beneath; Inflorescences terminal, of 2-5 many-flowered, \pm spherical verticillasters of large orange flowers. Bracts leaf-like, bracteoles spinescent. Flowers with calyx tubular, ca. $1.5 \mathrm{~cm}$ at flowering, 10-nerved, 8-10 lobed, lobes spinescent, posterior lobe 4-5 $\mathrm{mm}$, much longer than the others. Corolla ca. $2.2 \mathrm{~cm}$ long, tubular, deeply 2-lipped, appearing orange due to a dense indumentum of orange-coloured hairs, upper lip entire, hooded, almost as long as the curved tube, lower lip 3-lobed, soon withering. Stamens 4 , inserted near the throat of the corolla and directed under the upper lip, the anterior pair of stamens longer. Nutlets black, smooth.

Material selected: Parauapebas, Serra Norte, fim da estrada (Aceiro) partindo em frente ao Viveiro do Sossego e onde a estrada encontra o Rio Parauapebas, 06²8'09.5'S, 5002'28.7'W, 03.II.2011, L. Tyski 48 (HJCS); Serra dos Carajás, a margem da rodovia PA-275, próximo a Olaria sentido Carajás. 03.XI.1989, J.P. Silva 629 (HCJS, MG).

The species is widespread in the Caribbean, in Central and South America as a common weed of cultivation and waste places. Flowering and fruiting from November to February. In the Serra dos Carajás it is almost certainly under-recorded, and further records from the area can be expected.

6. Marsypianthes Mart. ex Benth., Labiat. Gen. Spec. 64. 1833.

Subshrubs or perennial herbs, aromatic and glandular-viscid, belonging to subfamily Nepetoideae tribe Ocimeae subtribe Hyptidinae, with leaves simple, toothed; inflorescence cymose; cymes few-flowered or in lax, spherical heads; bracteoles narrow, forming a lax involucre; calyx actinomorphic, 5-lobed, lobes equal, broadly to narrowly deltate, apex acute to subulate, often widely spreading and reflexed in fruit; corolla 2-lipped, 5-lobed, violet-blue, lilac or rarely cream, anterior lip with median lobe much shorter than others; style jointed, deciduous above, its persistent, quadrangular base fused to carpels along their inner face; fruit of four nutlets cymbiform, with involute, fimbriate margins.Five to six species in savannas and coastal dunes, Brazil, Paraguay and Argentina, with one widespread species, recorded in Carajás, which extends north to Mexico.

6.1. Marsypianthes chamaedrys (Vahl) Kuntze, Revis. Gen. Pl. 524. 1891.

Fig. 2g; 5a-b

Short-lived perennial herb, 50-75 cm tall, viscid and aromatic, stems prostrate, decumbent to erect, often rooting at lower nodes. Cauline leaves pale green, thinly membranous, thinly or densely hairy with long, weak, gland-tipped hairs, the glands elongate, petiole $0.4-1.9(-3) \mathrm{cm}$ long, slender, lamina $1.8-4.2(-7.5) \times 0.8-2.2(-2.6) \mathrm{cm}$, ovate to lanceolate or slightly deltate, apex acute, rarely \pm rounded, base truncate to cuneate, narrowly attenuate along petiole, margin serrate to crenate. Inflorescence of shortly pedunculate, lax capitula from axils of foliaceous bracts, peduncles 0.2-2.4 $\mathrm{cm}$ long, slender, capitula \pm hemispherical, lax, 0.8-1.4 cm diam., ca. 7-10-fld, with a lax involucre of narrowly linear bracteoles, apex acute, the outer $<8.5 \times 0.4-0.6 \mathrm{~mm}$, slightly curved, green or bluishpurple-tinged, margin long-ciliate. Flowers with calyx ca. 5-7 mm long at anthesis, lobes deltate, calyx accrescent in fruit with lobes spreading to reflexed, tube gaping; corolla bluish-violet, ca. 6 $\mathrm{mm}$ long, style slender. Nutlets 2-2.5 × 1.8-2 mm, pale brown, inner surface strongly concave, with thin, involute, fimbriate margin.

Material selected: Canaã dos Carajás, Serra Sul, S11D, nas proximidades do Alojamento da TOPGEO, 06²3'50"S, $50^{\circ} 20^{\prime} 58^{\prime \prime} \mathrm{W}$, solo detrítico, 18.IV.2015, L.M.M. Carreira et 
al. 3412 (MG). Parauapebas, Serra Norte, N1, 0602'04'S, $50^{\circ} 17$ '13”'W, 694 m, 29.III.2015, R.M. Harley et al. 57118 (MG); N3, 27.III.2012, P.B. Meyer et al. 1261 (BHCB); N7, 0609'31'S, 50¹0'09.9'W, 709 m, 24.II.2016, R.M. Harley et al. 57381 (MG); próximo do Herbário de Carajás, HCJS, linha do Transmissão, $06^{\circ} 03$ '10.3”S, 5004'46.2'W, n.d.,
L. Tyski, 654 (HJCS); regeneração próximo ao aeroporto, 28.I.1985, O.C. Nascimento \& R.P. Bahia 1017 (MG); Serra dos Carajás, 28.VI.1976, B.G.S. Ribeiro 1400 (IAN). Serra do Rabo (Serra da Bocaina), estrada de acesso a serra, 06¹7'03”S, 4952'02'W, 600m, 19.XII.2010, N.F.O. Mota et al. 1983 (BHCB).

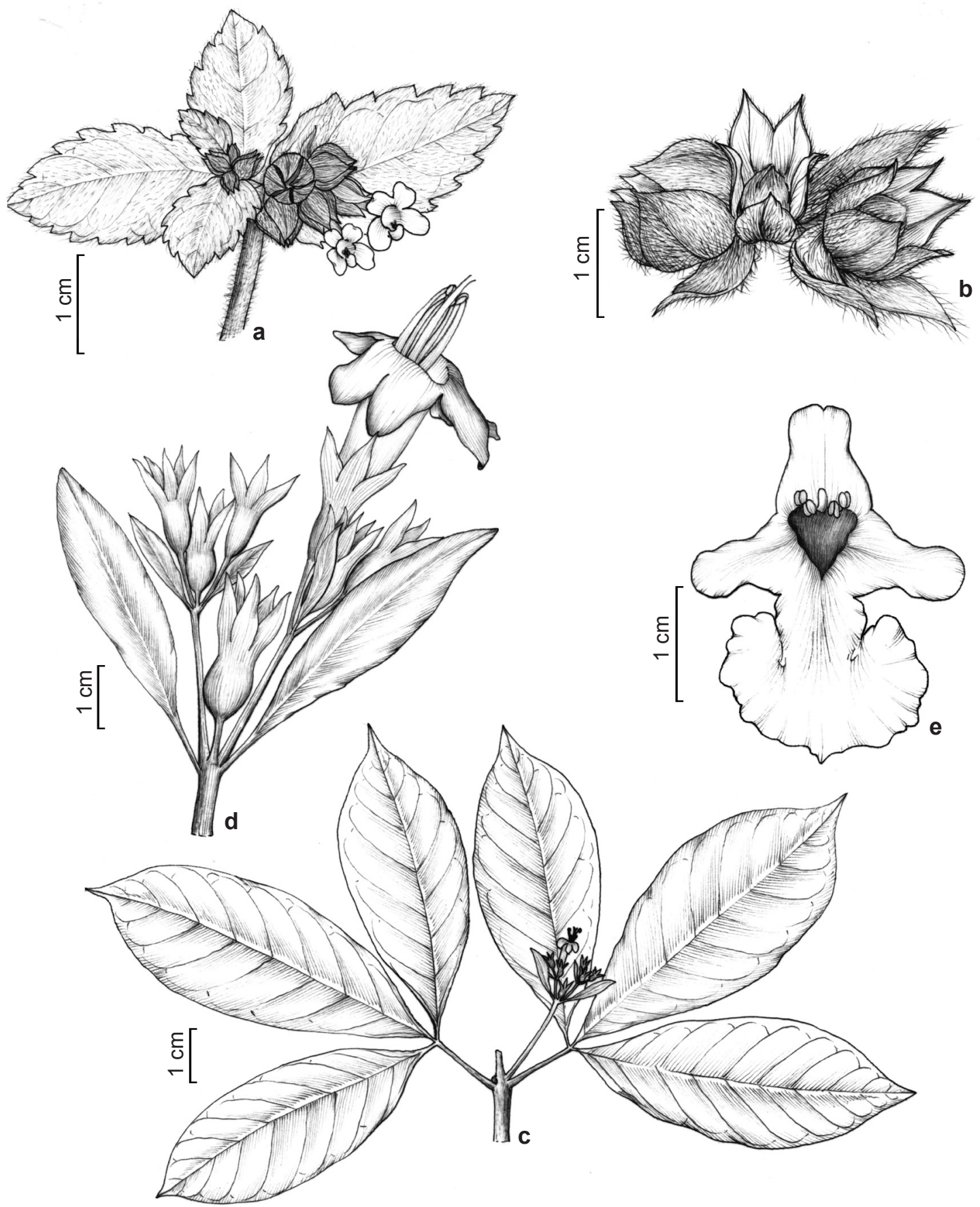

Figure 5 - a-b. Marsypianthes chamaedrys - a. inflorescence; b. fruiting calyces. c-e. Vitex trifolia - c. branch with inflorescence; $d$. inflorescence detail; e. corolla frontal view. 
The species is usually easily recognized by the procumbent to ascending habit, the slightly viscid leaves and the axillary, shortly pedunculate capitula of violet-blue flowers, the calyx with broadly deltate lobes, widely spreading in fruit, and the unique form of the nutlets.

The species is extremely variable throughout its range from Southern United States and the Caribbean, south through Central and South America to Peru and Brazil. It occurs in open, usually disturbed places in damp grassland. Flowering and fruiting throughout the year. In the Serra dos Carajás it is recorded from the Serra Norte, Serra Sul and Serra da Bocaina.
7. Mesosphaerum P. Browne, Civ. Nat. Hist. Jamaica: 257. 1756.

Annual or perennial herbs or shrubs, rarely small trees, belonging to subfamily Nepetoideae tribe Ocimeae subtribe Hyptidinae, with flowers shortly pedicellate, in usually lax, often cincinnate cymes, sometimes congested, or rarely capituliform, bracteoles small, not forming an involucre, calyx sub-actinomorphic, corolla small, gynoecium with gynobasic style, without a stylopodium. Fruit of 4 nutlets, ovoid to narrowly ellipsoid. About 25 species, primarily Andean, but extending from Mexico southwards to Brazil. Two species are now pantropical weeds.

\section{Key to species of Mesosphaerum from the canga of the Serra dos Carajás}

1. Weakly aromatic non-viscous herb or shrub. Corolla $<2.5 \mathrm{~mm}$ long, pale pinkish. Fruiting calyx tubular-ellipsoid $<3.5-4 \mathrm{~mm}$ long with ring of white hairs in throat, lobes not spinose. Nutlets ca. 1.1 mm long, four per calyx. 7.1. Mesosphaerum pectinatum

1'. Strongly aromatic viscous herb or shrub. Corolla $7-8 \mathrm{~mm}$ long, lilac or white. Fruiting calyx tubularcampanulate, slightly compressed, $8.5-9 \mathrm{~mm}$ long, without a conspicuous ring of hairs in throat, lobes weakly spinose. Nutlets ca. $3.5 \mathrm{~mm}$ long, usually only two per calyx

7.2. Mesosphaerum suaveolens

7.1. Mesosphaerum pectinatum (L.) Kuntze, Revis. Gen. P1.: 525. 1891. = Hyptis pectinata (L.) Poit. (1806).

Fig. $2 \mathrm{~h} ; 4 \mathrm{k}$

Robust, annual to perennial herb, 1-2(-3) $\mathrm{m}$ tall, weakly aromatic, stems erect, branched, quadrangular, often with small, retrorse prickles on angles. Cauline leaves with petiole $(-) 1.5-3.5(-4) \mathrm{cm}$, densely and shortly hairy, lamina (2-)4-7 × (2.5-)3$4.5 \mathrm{~cm}$, ovate, membranous, apex acuminate, base weakly cordate to truncate or rounded, margin doubly serrate or weakly lobed, upper surface dark green, thinly to rather densely pilose, lower surface paler, grey-tomentose, with sessile glands. Inflorescence a narrowly elongate or spiciform, terminal thyrse to $40 \mathrm{~cm}$ or more long, branches fastigiate, cymules 20 - to 40 -flowered, appearing 1-sided, with lowest node forming a dichasium and the two branches cincinnate, flowers second, held erect, cyme axis becoming cernuous, bracteoles $2-4 \mathrm{~mm}$ long, filiform. Flowers subsessile, calyx at anthesis $1.75-2 \mathrm{~mm}$ long, subulate, fruiting calyx accrescent 3.5-4(-5) $\mathrm{mm}$ long, tube narrowly ellipsoidal, throat fringed with white hairs, lobes $1-1.5(-2) \mathrm{mm}$ long, erect. Corolla pale, dull, pinkish-purple, sometimes tinged yellowish, $2.5 \mathrm{~mm}$ long, tube $1.5-1.75 \mathrm{~mm}$ long. Nutlets $1.1 \times 0.5 \mathrm{~mm}$ long, narrowly oblong-ovoid, black or dark brown, finely rugulose.
Material selected: Canaã dos Carajás, Serra Sul, S11D no acampamento, 30.III.2015, Cardoso et al. 1996 (MG). Parauapebas, Serra Norte, arredores da estrada para N1, 17.IV.1982, R. Secco et al. 207 (MG); N3, 0602'44"S, 50¹3'09”'W, 692 m, 27.III.2012, A.J. Arruda et al. 889 $(\mathrm{BHCB}) ; \mathrm{N} 4$, próximo a transição para a mata de terra firme, 19.III.1984, A.S.L. Silva et al. 1888 (MG, INPA).

Throughout much of tropical America from Southern United States (Florida) and the Caribbean to South America, to Peru and Bolivia. Few records from Amazonian Brazil, but common and widespread further South. Introduced in tropical Africa, Asia and the Pacific. A weed of cultivated ground, roadsides, forest margins and waste places. Flowering and fruiting from September to May. In the Serra dos Carajás, only in the Serra Norte as an introduced weed.

7.2. Mesosphaerum suaveolens (L.) Kuntze, Revis. Gen. Pl.: 525. 1891.

= Hyptis suaveolens $(\mathrm{L}$.) Poit.

Fig. 2i; 41-n

Annual herb to subshrub, 0.5-2 $\mathrm{m}$ tall, strongly aromatic, viscid, erect, branched, branches ascending, stems quadrangular, often rather densely hairy. Leaves densely hairy with petiole (2-)4-5 $\mathrm{cm}$ long, lamina 4-8.5 $\times 2-5.3 \mathrm{~cm}$, ovate, smaller in upper part of stem, membranous, green, apex acute, base strongly cordate, margin irregularly 
serrate, often weakly lobed. Inflorescence a robust, branched, terminal thyrse with long, straight ascending branches, bracts small, usually leafy with an axillary cyme, and often a superposed axillary flowering branch, cymes (3-)5-6-fld, bracteolate, bracteoles inconspicuous, linear, peduncles 6-8(-10) mm. Flowers \pm sessile, calyx at anthesis ca. $5 \mathrm{~mm}$, tube infundibuliform, prominently 9-nerved, hairy with sessile glands, glabrous within, lobes $1.5-2 \mathrm{~mm}$ slightly unequal, with long subulate apex, with wide, strongly ciliate sinus, fruiting calyx c. $8.5-9 \mathrm{~mm}$ long, $3.5-4 \mathrm{~mm}$ wide below throat, tube tubular-campanulate, slightly compressed, hairy in throat, lobes ca $2.5 \mathrm{~mm}$, slightly spinose-tipped, corolla $7-8 \mathrm{~mm}$, lilac or white, tube 5-6 mm, with darker markings at base of upper lip. Nutlets $3.5 \times 2.5 \mathrm{~mm}$. compressed, broadly rotund glabrous, dark brown, only two nutlets normally developing per flower.

Material selected: Canaã dos Carajás, Serra do Tarzan, 28.III.2015, R.M. Harley et al. 57113 (MG); Racha placa, ADA Usina S11, $06^{\circ} 27^{\prime} 01$ 'S, $50^{\circ} 12^{\prime} 12^{\prime \prime} \mathrm{W}$, 28.I.2012, L.F.A. Paula et al. 491 (BHCB). Parauapebas, Serra Norte, N8, acesso ao final do corpo, $06^{\circ} 09^{\prime} 43^{\prime \prime}$, 5009'53”'W, 14.V.2010, L. Tyski 679 (HJCS); Pedra do Mirante, 580 m, 22.III.2012, A.J. Arruda et al. 777 (BHCB); Área do Rejeito do aeroporto, lado esquerdo do PBT, 19.XII.1988, J.P. Silva 287 (HCJS); Serra do Rabo (Serra da Bocaina) 06 $18^{\prime} 27^{\prime \prime} \mathrm{S}, 49^{\circ} 53^{\prime} 21^{\prime \prime} \mathrm{W}$, 725 m, 16.XII.2010, N.F.O. Mota et al. 1918 (BHCB).

This species is widespread throughout the Tropics, as an often serious weed of cultivation. Frequent along roadsides, abandoned cultivation and disturbed areas by rivers and forest margins. Throughout Brazil, except the extreme South. Flowering and fruiting from March to November. In the Serra dos Carajás it is recorded from the Serra Norte, Serra Sul and Serra da Bocaina.

\section{Vitex L. Sp. Pl. 2: 638. 1753.}

Trees or shrubs, belonging to subfamily Viticoideae, with leaves usually digitately compound with 3-8 leaflets but sometimes unifoliolate, inflorescence axillary or terminal, a dichasial cyme, sometimes compound forming a thyrse or panicle, flower wth corolla blue, yellow, white to purple; calyx 3-5-lobed, or truncate, actinomorphic to weakly 2-lipped; corolla 5-lobed, 2-lipped, stamens 4 , didynamous, attached near base of tube; often exserted, gynoecium with terminal style, bicarpellate, carpels 2-locular and 2-seeded; fruit drupaceous, with hard pyrene, 4-seeded. Ca. 250 species, in both Old and New World tropics, and a few in temperate or subtropical regions. About 32 species in Brazil.
8.1. Vitex triflora Vahl, Eclog. Amer. 2: 49. 1798.

Fig. 2j; $5 \mathrm{c}-\mathrm{e}$

Tree or shrub to $5 \mathrm{~m}$ tall, often less in open situations. Young stems with tawny indumentum. Leaves trifoliolate, leaflets subequal, 6-35 $\times 3-10 \mathrm{~cm}$, chartaceous, green, slightly discolorous, broadly elliptic-oblanceolate, base gradually attenuate to a short petiole, apex abruptly acuminate, margin entire, adaxial surface glabrous, darker green, abaxial surface subglabrous with tawny indumentum along midrib and primary veins. Flowers in axillary pedunculate, few-flowered axillary cymes, from axils of upper leaves; peduncles $1.5-5 \mathrm{~cm}$ long. Cymes \pm dichasial, 2-7-flowered, bracteoles narrowly linear, inconspicuous or rarely leafy; calyx green, or purple tinged, $1.7-2 \mathrm{~cm}$ long, 2-lipped, tube narrowly cylindrical, ca. $1 \mathrm{~cm}$ long, indumentum tawny, lobes lanceolate, acute, 6-8 $\mathrm{mm}$ long, corolla 2-lipped, tube, ca. $2 \mathrm{~cm}$ long, pale, externally with tawny indumentums, lobes 4-5 mm long, patent, lilac to deep bluish purple. Stamens 4, exserted, style slender, exserted, bifurcate. Fruit $1.4 \times 1 \mathrm{~cm}$, ovoid, green, with persistent calyx.

Material selected: Canaã dos Carajás, Serra do Tarzan, na beira da mata da canga, $06^{\circ} 19^{\prime} 46,8^{\prime \prime} \mathrm{S}, 50^{\circ} 07^{\prime} 52,5^{\prime \prime} \mathrm{W}$, 732 m, 01.IX.2015, R.M. Harley et al. 57345 (MG); Serra Sul, S11A, 06²0'28”'S, 50²7'05”'W, 658 m, 04.X.2009, V.T. Giorni \& F. Marino 339 (BHCB); S11B, $700 \mathrm{~m}$, 03.VIII.2010, L.V.C. Silva et al. 982 (MG, BHCB, RB); S11D, 06 23'27'’S, 50²1'03'W, 700 m, 29.IX.2009, V.T. Giorni \& F. Marino 292 (BHCB, HCJS). Parauapebas, Serra Norte, N1, $6 \mathrm{~km}$ SE of AMZA camp, 06 $03^{\circ}$ 'S, $50^{\circ} 16^{\prime} \mathrm{W}, 650 \mathrm{~m}, 19 . \mathrm{V} .1982$, C.R. Sperling et al. 5762 (MG); Arredores da estrada para N1, 17.V.1982, R. Secco et al. 248 (MG, MO); N4E, 29.VI.1987, C.M. Araujo 133 (HCJS); N5, $5 \mathrm{~km} \mathrm{~W}$ of AMZA camp, 06 04 'S, 50 $10^{\prime} \mathrm{W}, 700-800 \mathrm{~m}, 15 . \mathrm{V} .1982$, C.R. Sperling et al. 5693 (MG, NY); Serra dos Carajás, AMZA camp 3-Alfa, $05^{\circ} 48^{\prime} \mathrm{S}, 50^{\circ} 33^{\prime} \mathrm{W}, 475-525 \mathrm{~m}, 07 . \mathrm{VI} .1982$ C.R. Sperling et al. 5959 (MG); Serra Norte, estrada PA-275, $48 \mathrm{~km}$ do acampamento, 06.VIII.1982, U.N. Maciel et al. 764 (MG, IAN, NY); Serra Norte, Mina de manganês H7, 01.VI.1983, M.F.F. Silva et al. 1430 (MG); Parque Zoo-botânico de Carajás, 29.VII.2007 D.F. Silva et al. 7 (HCJS); Serra dos Carajás, 28.VI.1976, B.G.S. Ribeiro 1413 (IAN); Serra da Bocaina, na beira da mata da canga, 06 03 '48,3”S, 5003'31.6”'W, 879 m, 23.VI.2015, R.M. Harley et al. 57265 (MG).

Vitex triflora has its centre of distribution in forest regions of Amazonian Brazil, and extends into the Guianas and westward, from Venezuela to Peru and Bolivia, also recorded in forest bordering cerrado in NE and Central Brazil. A frequent shrub 
or small tree along the low woodland, bordering canga vegetation. Flowering from May to October. In the Serra dos Carajás it has been recorded from the Serra Sul, the Serra do Tarzan, the Serra Norte and the Serra da Bocaina.

\section{Acknowledgements}

I would like to thank the Curators and staff of the Herbaria of the Museu Paraense Emilio Goeldi (MG), and of EMBRAPA Meio-Norte (IAN) and also the staff at the Instituto Tecnológico Vale, in Belém, for their assistance in furthering my research and allowing me access to their collections. I would also like to acknowledge staff at ICMBio, and especially Frederico Drumond Martins, for granting me a collecting licence and in giving unstinting help, ensuring our successful fieldwork. Thanks are also due to Carla Teixeira Lima for producing the illustrations. I should also like to thank CNPq and the Museu Goeldi for the grant under the "Programa de Capacitação Institucional - PCI-E1", and for the financial support for the projects MPEG/ITV/ FADESP (01205.000250/2014-10) and CNPq ( 455505/2014-4).

\section{References}

Bentham, G. 1833. Labiatarum genera et species. Ridgeway \& Sons, London. Pp. 62-145.

Bentham, G. 1848. Labiatae. In: Candolle, A.L.P.P. de (ed.) Prodromus systematis naturalis regni vegetabilis 12. V.Masson, Paris. Pp. 27-603.

BFG. 2015. Growing knowledge: an overview of seed plant diversity in Brazil. Rodriguésia 66: 1085-1113.

Briquet, J. 1897. Labiatae in Engler \& Prantl (eds.). Naturlichen Pflanzenfamilien 4. Abt. 3a: 332-348.

Epling, C.1935. Synopsis of the South American Labiatae, 1. Repertorium specierum novarum regni vegetabilis. Beihefte 85: 1-96.

Epling, C. 1936a. Synopsis of the South American Labiatae, 2. Repertorium specierum novarum regni vegetabilis. Beihefte 85: 97-192.

Epling, C. 1936b. Synopsis of the South American Labiatae, 3. Repertorium specierum novarum regni vegetabilis. Beihefte 85: 193-288.
Epling, C. 1936c. Notes on the Distribution of Hyptis in the Old World. Kew Bull. 4: 279.

Epling, C. 1937. Synopsis of the South American Labiatae, 4. Repertorium specierum novarum regni vegetabilis, Beihefte 85: 289-341.

Epling, C. 1949. Revisión del género Hyptis (Labiatae). Revista del Museo de La Plata, Sección Botánica 7: 153-497.

França, F. 2003. Revisão de Aegiphila Jacq. (Lamiaceae). Tese de Doutorado. Universidade de São Paulo, São Paulo. 500p.

França, F. \& Giulietti, A.M. 2012. Lectotypifications, Neotypifications and Epitypifications in the genus Aegiphila Jacq. Neodiversity 6: 1-14.

Harley, R.M. 1983. Notes on New World Labiatae IV. A taxonomic revision of Hyptis recurvata and its allies. Kew Bull. 37: 637-642.

Harley, R.M. 2012. Checklist and key of genera and species of the Lamiaceae of the Brazilian Amazon. Rodriguesia 63: 129-144.

Harley, R.M.; Atkins, S.; Budantsev, A.; Cantino, P.D.; Conn, B.; Grayer, R.; Harley, M.M.; Kok, R. de; Krestovskaja, T.; Morales, A.; Paton, A.J.; Ryding, O. \& Upson, T. 2004. Labiatae. In: Kadereit, J.W. (ed.) The families and genera of vascular plants 7. Springer, Berlin \& Heidelberg. Pp. 167-275.

Harley, R.M. \& Pastore, J.F.B. 2012. A generic revision and new combinations in the Hyptidineae (Lamiaceae), based on molecular and morphological evidence. Phytotaxa 58: 1-58.

Pastore, J.F.B.; Harley, R.M.; Forrest, F.; Paton, A.J. \& van den Berg, C. 2011. Phylogeny of the subtribe Hyptidinae (Lamiaceae tribe Ocimeae) as inferred from nuclear and plastid DNA. Taxon 60: 13171329.

Moldenke, H.N. 1939. A monograph of the genus Amasonia. Repertorium specierum novarum regni vegetabilis, 46: 193-228.

Sampaio, A.J. \& Perckolt, O. (1943) A nomenclatura das espécies na Flora Fluminensis de Conceição Vellozo e sua correspondência atual. Arquivos do Museu Nacional 33: 333-394.

Santos, J.S. dos; França, F.; da Silva, M.J. \& de Sales, M.F. 2012. Levantamento das espécies de Amasonia (Lamiaceae) para o Brasil. Rodriguesia 63: 1101-1116. 


\section{Lista de exsicatas}

Almeida, T.E. 2454 (8.1). Araujo, C.M. 133(8.1). Arruda, A.J. 310(8.1), 509(7.2), 591 (4.1), 680(3.1), 777(7.2), 889(7.1), 929(4.1), 1056(4.3), 1253(4.4). Bastos, J.A.A. 189(3.1). Cardoso, A. 1978 (1.1), 1986 (6.1), 1990 (4.1), 1996 (7.1). Carreira, L.M.M. 3412 (6.1). Cavalcante, P. 2134 (2.2), 2184, 2694 (2.3). Costa, L.V. 817 (2.3), 832 (2.1), 982 (8.1), 1047(4.4). Giorno, V.T. 100 (2.1), 109 , 237 (2.3), 292, 339 (8.1). Harley, R.M. 57112 (4.1), 57113(7.2), 57114 (4.1), 57118 (6.1), 57124 (4.1), $57136(2.1), 57265(8.1), 57292$ (4.4), 57300(3.1), 57311(7.1), 57345(8.1), 57363(2.1), 57415(1.1), 57421(7.2), 57481(2.1), 57488(1.1), 57456(4.3), 57983(8.1). Lima, M.P.M. 91(1.2). Lobato, L.C.B. 3826(4.3). Maciel, U.N. 764(8.1). Meyer, P.B. 1198(2.3), 1224(4.3), 1261(6.1). Mota, N.F.O. 1190 (2.3), 1858(4.2), 1918 (7.2), 1973(3.2), 1983(6.1), 2998(2.3), 3016(4.2), 3405(1.1). Nascimento, O.C. 951 (1.1), 1017 (6.1), 1034 (2.3), 1081(1.2). Paula, L.F.A. 491(7.2). Pivari, M.O. 1534(4.1). Ribeiro, B.G.S. 1400(6.1), 1413(8.1). Rocha, A.E.S. 1818(2.2). Rodrigues, I.M.C. 576(4.1). Rosa, N.A. 4658(3.1), 4700(2.3), 4748(2.1). Secco, R.S. 170(2.3), 207(7.1), 248(8.1), 454(2.1), 573(4.3), 695(4.3). Silva, A.S.L. 1813(2.1), 1827(1.1), 1888(7.1), 1930(2.3). Silva, D.F. 7(8.1). Silva, J.P. 242(1.1), 287(7.2), 454(4.1), 629(5.1). Silva, L.V.C. 1230 (3.2), 1276(4.1). Silva, M.C. 2864(2.3). Silva, M.F. 1430(8.1). Silva, M.G. 2938(1.1), 3032(8.1). Sperling, C.R. 5693(8.1), 5695 (1.1), 5762 (8.1), 5767(2.3), 5959(8.1), 6264(4.3). Trindade, J.R. 218(6.1), 249(7.1). Tyski, L. 48(5.1), 192(4.1), 654(6.1), 662(4.1). Viana, P.L. 3453(4.3), 5573(2.3), 5610(2.2), 5652(2.1), 5670 (2.3), 5677(2.3). Zocche, J.J. s.n.(4.4). 